\title{
Voting Results Concurrent Election in Indonesia in 2019
}

\author{
Maemunah' \\ ${ }^{1}$ Pendidikan Pancasila dan Kewarganegaraan, Universitas Muhammadiyah Mataram, maemunah.mahmudabdullah@gmail.com
}

\begin{tabular}{l} 
INFO ARTIKEL \\
\hline Riwayat Artikel: \\
Diterima: 14 September \\
2020 \\
Disetujui: 30 September \\
2020
\end{tabular}

\section{Kata Kunci:}

Voting

Concurrent

Election

\begin{abstract}
ABSTRAK
Abstrak: Dalam konteks Indonesia yang sedang membangun peradaban politik yang sehat, penyelenggaraan pemilu tanpa kehadiran pengawasan struktural dan fungsional yang intens berpotensi mengakibatkan hilangnya hak pilih warga negara, bangkitnya politik uang, kampanye hitam, dan pemilu. yang tidak sesuai aturan. Tulisan ini bertujuan untuk mengetahui hasil pemungutan suara pemilu serentak di Indonesia tahun 2019. Penelitian ini menggunakan pendekatan deskriptif analitik. Berdasarkan hasil penelitian menunjukkaan bahwa pelaksanaan pemilu serentak merupakan sejarah baru di Indonesia karena pelaksanaan secara serentak mulai pemilihan cadidat tiangkat pusat hingga daerah. Adanya pemilu serentak ini dapat memberikan catatan baru bila dibandingkan dengan pemilu sebelumnya, pemilu serentak ini menghasilkan beberapa hal penting terhadap pemilu Indonesia yaitu dapat mengefisiensi anggaran dana, partisipasi partai politik secara ketat, partisipasi peserta pemilu dan menghasilkan calon presdient dan wakil presiden, anggota legislative dan dewan perwakilan daerah yang terpilih sesuai pilihan rakyat.
\end{abstract}

\begin{abstract}
In the sense of Indonesia which is building a stable democratic civilization, it is possible to hold elections without intensive institutional and functional oversight that can result in the erosion of the rights of people to vote, an increase in money policy, black campaigns and elections. The rules don't suit. The goal of this paper is to determine the outcome of the 2019 simultaneous elections in Indonesia. This research uses an analyticaldescriptive approach. The results show that the conduct of concurrent elections is a new history in Indonesia because the success begins at the same time from election of central to regional candidates. The simultaneous election will provide new records compared with previous elections, which will produce many critical elements in the Indonesian elections, namely the ability to simplify the budget, tight political party membership, participation of electoral participants and the presidential and vice-presidential candidates, parliamentarians and members of the Parliament.
\end{abstract}

\section{A. INTRODUCTION}

In the context of Indonesia, which is building a healthy political civilization, holding elections without the presence of intense structural and functional oversight has the potential to lead to the loss of citizens' voting rights, the rise of money politics, black campaigns, and elections that are not according to rules. The continued impact of ballots with no integrity is the emergence of disputes and lawsuits on election results. Also, the democratic party is high-cost, but will only produce leaders whose legality and legitimacy is doubtful. The next potential danger is the endless political conflict[1];[2].

Previous research on the holding of political perspective The introduction of general elections in 2019, referring to the decision of the Constitutional Court, is more likely to support the political side than this legislation is considered to guarantee the legitimacy of political parties against the Constitutional Court. In effect, whatever the Constitutional Court determines is a final decision, where the Constitutional Court is a state agency entitled to interpret the constitution. Construction of constitutional law in accordance in 2019 applies to Court Decision No. 14 / PUU-XI/2013 enabling simultaneous elections in the Republic of Indonesia, not technically contrary to the provisions of the Republic of Indonesia Constitution of 1945[3]. In the 2019 General Election performance, it is the collective responsibility of all election stakeholders, in this case government, election participants, and election organizers[4]. The outcome of this research is that most of the KPU Regulations established during the 2019 Concurrent Election process provided legal certainty, although there are some KPU Regulations that are not in line with the above legislation. Basically, this KPU regulation offers legal clarity when it comes to profit and justice[5] Overcoming the need for political support, the 2019 Concurrent Election implementation was approved as a compromise in which the simultaneous scheduling of presidential and legislative elections promoted a constructive relationship with the amount of presidential 
political support in the legislature. But in fact, the reforms in the electoral system resulted in a major coattail effect and the subsequent government management was still based on a pragmatic working coalition.[6] Other to reveal that the objectives and material presented in the implementation of political education are still oriented towards strengthening internal party institutions as an effort to strengthen ideology, winning strategies and internal party consolidation.[7]

Some of the above studies focus more on the simultaneous application of election laws, the importance of stakeholders in election administration, election regulation, and the impact on simultaneous elections. Meanwhile, there are not many aspects of studies explaining the results of simultaneous elections that describe quantitatively, politically, economically, and legally. This article focuses on explaining the results of the 2019 simultaneous election voting through quick calculations. The results of the 2019 simultaneous elections in Indonesia are carried out in a direct, free, and fair manner with the provisions of the presidential and vice-presidential elections, legislative members and regents/mayors and governors.

As it is known, the Concurrent Election Decision is the Constitutional Court 's 2014 decision on the public review of Law No. 42 of 2008 on the Presidential and Vice-Presidential Election[8] The Constitutional Court considers the provisions of Article 22E Paragraph (1) of the Constitution of 1945, which states: "General elections are held explicitly, openly, anonymously, secretly, honestly and reasonably every five years." Simply put, it can be understood that the Constitution of 1945 mandates only one general election in five (5) years. This is reflected in the original intention to do so during the debate of the changes to the 1945 Constitution, where the meeting decided that elections should be held every five years.[9]

In its growth, this decision can also apply to the concept of possible burnout for voters facing multiple elections. Running elections that could burnout voters many times, which are eventually feared could result in average voter participation, and it may be that while the participation still shows a decent number, people are lazy to care about the content of why elections or why they should go to polling stations or why they should engage in elections.[10] Moreover, whether the recent election was an election involving crime, or an election that eventually did not produce members of people in the legislature and leaders of people in executive ranks who did not perform well, the Concurrent Election is most likely formulated to close the saturation gap. Another possibility, the Concurrent Election is an excuse to make election administration effective.[11] The purpose of this article is to find out the results of simultaneous election voting in Indonesia in 2019.

\section{B. RESEARCH METHOD}

This characteristic of our research is applying qualitative content analysis methods. This research used a descriptive-analytical approach. The approach used to find data on the implementation of elections in indonesia.

\subsection{Data Collection}

a. Study Literature

Study literature is used to analyze research reports, election policy results and articles about simultaneous elections.

\section{b. Document Analysis}

Document analysis used to analyze and identify various performance report documents about is report the election.

\subsection{Data Analysis}

Primary and secondary data documents are collected, then the analysis process is carried out using an interactive analysis model. The analysis consists of three activities that coincide: data reduction, data presentation, concluding/verification related to by the election in Indonesian.

\section{RESULT AND DISCUSSION}

The Supreme Court's decision of 23 January 2014 in the Yudicial Reform of Law No. 42/2008 laid the groundwork for simultaneous elections in 2019. The decision was stated in Supreme Court Decision 14 / PUU-XI/2013.[12];[13] Following the legislative elections which had taken place, the Constitutional Court found the operation of the presidential election in breach of the constitution and deemed it to be a devolution. The President must have a powerful legislature role in a presidential structure as Head of State and Government and the two institutions must be independent. In Indonesian practice as a multiparty president, however, disputes and deadlock relations between the two institutions are often experienced.[14];[15] The good news is that the President's scheme is already demonstrating that political stability is preserved in current government practice.[16] However, the new presidential election is fearful that the outcome of the legislative election will be controlled by the outcome that all political parties can not necessarily propose candidadte pairs for the presidential elections , political parties or a coalition of parties, which meet the threshold for votes or a particular minimum seat that can nominate presidential and vice-presidential candidates.

The simultaneous general election is a new history in the State of Indonesia. This simultaneous election the Indonesian people carry out simultaneous direct polls starting from the election of presidential and vicepresidential candidates, candidates for legislative members, and members of the regional representative council. This general election holds the principle of a vote which is honest, fair, free, direct, and confidential. The general elections culminated in the elections for 
executive candidates, namely the president and vice presidente, then representatives of the parliament, namely the Republic of Indonesia's House of Representatives, the Provincial Regional Chamber of Representatives and the Regency/City Regional House of Representatives. In the following, we describe the results of the simultaneous general elections in 2019.

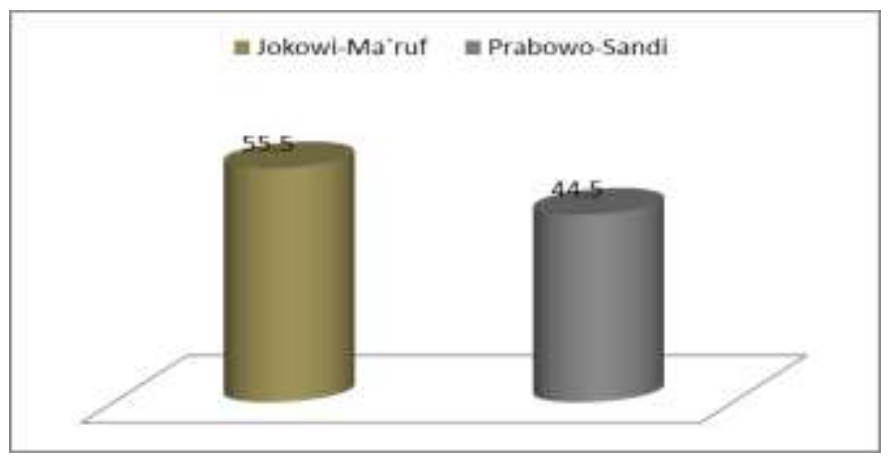

Fig 1. Results of executive elections

The official recapitulation results of the Republic of Indonesia Election Commission explained that the presidential and vice-presidential pair Jokowi - Ma'ruf won $85,607,362$ votes or 55.50 percent, 16.95 million votes ahead of Prabowo - Sandiaga who got 68,650,239 votes or 44,50 percent. So the winners in the general election for executive positions (president and vicepresident) are candidate pairs Joko Widodo and $\mathrm{KH}$. Ma'ruf Amin won the highest vote. The victory was under the general election rules, which reached above 50 percent.

Presidential and vice-presidential elections, the system is carried out with direct elections are candidates who get the most votes determined as elected president, candidates who get the most votes are determined as winners indirect elections.[17];[18], Likewise, another view explains that runoff with a reduced threshold (majority conditional) in the presidential election system is the primary choice. The requirements applied are the pair of President and Vice President elected in the first round if they won $45 \%$ of the vote with a distance of 5 percent from the second candidate, or $40 \%$ of the vote with a range of $10 \%$ of the vote from the second candidate.[19];[20]

The presentations of selected candidates for parliamentarians throughout Indonesia, both for members of the House of Representatives of the Republic of Indonesia (DPR RI), the Regional Provincial House of Representatives (DPRD Provincial) and the Regional Representatives' Council (DPRD) are also represented in figures.

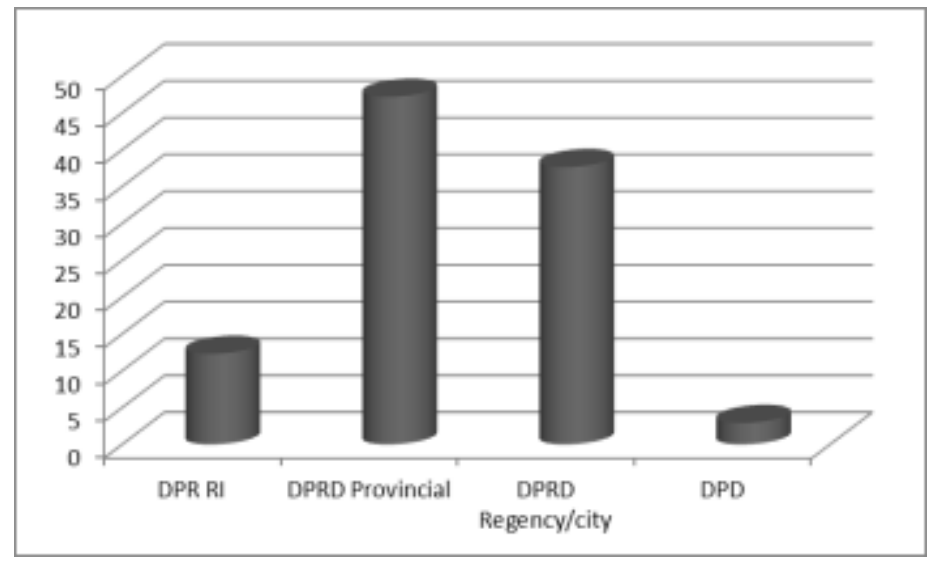

Fig 2. Members of Parliament throughout Indonesia for the period 2019-2024

Based on the results of the general election simultaneously produced 4,679 elected legislators. In the election of the legislative members, it was identified that the highest number of members was the Regional Representative Council (DPRD) of the Province of $49 \%$. In comparison, the least legislative members were the members of the Regional Representative Council (DPD) reaching 5\%, while other Regional Representatives Council (DPRD) reached 40\%, and the DPR RI reached 14\%. Simultaneous elections were held in the presidential and vice-presidential polls and legislative members aimed at streamlining the funding budget for the holding of elections and simplifying general elections as well as efforts to strengthen the democratic system in Indonesia.

Referring to democracy in simultaneous elections, the deepening of democracy can be seen as an effort to realize an effective government. The state and the people should work together so that they can strengthen each other's roles.[21]. The simultaneous national election was expected to strengthen the legislative and executive relations within the framework of checks and balances desired by the constitution to create a more stable and effective government in the context of the presidential government system that has been conceptualized in the 1945 Constitution.[22] The threshold in legislative elections indicates that the electability of political parties to meet the most votes is the main objective to get as many votes as possible to win seats in parliament above 4 percent or win in general elections.[23];[24]

Furthermore, the votes obtained for the legislative elections in 2019, determined by the General Election Commission of the Republic of Indonesia were based on the highest to lowest votes, as follows: 


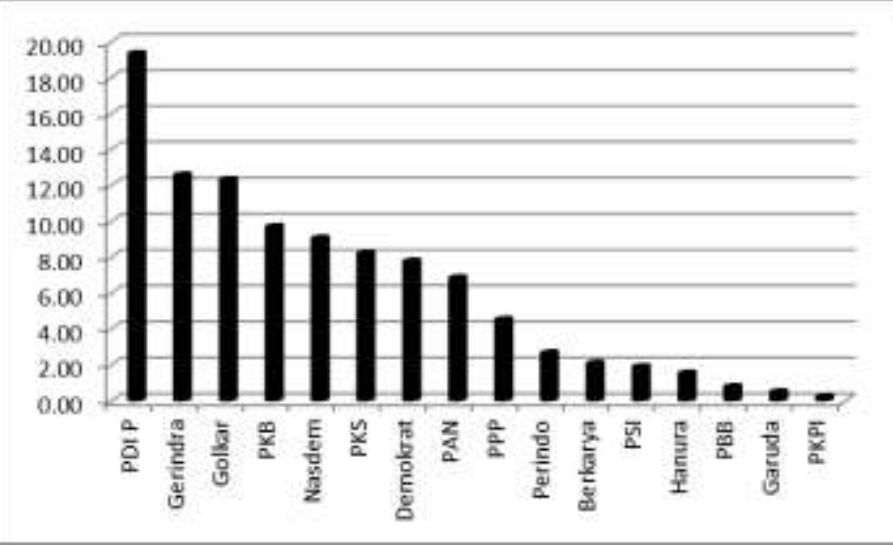

Fig 3. Political Parties that passed in Parliament at the 2019 Concurrent Elections

The party category received the most votes reaching 19.58\%, namely the Indonesian Democratic Party of Struggle Party (PDIP), while the lowest party was the Indonesian Justice and Unity Party (PKPI), reaching 1\%. In the Indonesian republic, electoral provisions that qualify nationally are political parties obtaining more than $4 \%$ of the national vote; otherwise, the party falls (does not restrict parliament). In the legislative elections using a proportional system with a standard provision of at least $4 \%$ of votes obtained from the votes of political parties, if the opponent does not reach the $4 \%$ provision, it will fail. Proportionally nine national political parties qualify in parliament, while seven political parties do not qualify for parliament because they do not reach $4 \%$ of the national vote, while the seven parties are Perindo party, working party, PSI party, Hanura party, PBB party, Garuda party and PKPI party. Because legally contained in Law Number 7 the Year 2017 article 414 explains that political parties participating in the election must meet the threshold of vote acquisition of at least $4 \%$ (four percent) of the number of valid votes nationally to be included in determining the purchase of seats for members of the House of Representatives.[25];[26]

While other opinions explain the research findings, the political ideology in recent Indonesia is declining, and towards the end of the doctrine. If so, it will affect the party system in Indonesia and be known as "depoliticization of the party" due to a lack of confidence between citizens. There could be some evidence to prove that. Firstly, the party 's answer to the issue of the parliamentary threshold is no longer political.[27];[28] Based on the report of the Honorary Board of Election Organizers in the implementation of general elections simultaneously has resulted in several election disputes that have resolved several dispute violations of the code of ethics carried out by the election organizer.

\section{CONCLUSIONS AND SUGGESTIONS}

The results of the research show that the implementation of simultaneous elections is a new history in Indonesia because the performance is simultaneously starting from the election of candidates for the central to regional levels. The existence of this simultaneous election can provide a new record when compared to previous elections; this simultaneous election produces several important things for the Indonesian election, namely being able to streamline the budget, tight political party participation, the participation of election participants, and create presidential and vice-presidential candidates, legislative members and regional representative council elected according to the people's choice.

\section{REFERENCE}

[1] F. M. Coma and C. Van Ham, "Can experts judge elections? Testing the validity of expert judgments for measuring election integrity," Eur. J. Polit. Res., vol. 54, no. 2, pp. 305-325, 2015.

[2] A. Clark, "Identifying the determinants of electoral integrity and administration in advanced democracies: the case of Britain," Eur. Polit. Sci. Rev., vol. 9, no. 3, pp. 471-492, 2017.

[3] C. Van Ham and S. Lindberg, "When Guardians Matter Most: Exploring the conditions under which electoral management body institutional design affects election integrity," Irish Polit. Stud., vol. 30, no. 4, pp. 454-481, 2015.

[4] M. Rahmatunnisa, "Mengapa Integritas Pemilu Penting?," J. Bawaslu, vol. 3, no. 1, pp. 1-11, 2017.

[5] A. Salwa, Y. Away, and M. Tabrani, "Pengaruh Komitmen, Integritas Dan Kompetensi Terhadap Kinerja Pegawai Serta Dampaknya Pada Kinerja Komisi Independen Pemilihan (KIP) Aceh," J. Magister Manaj., vol. 2, no. 1, pp. 58-67, 2018.

[6] F. Corò, E. Cruciani, G. D'Angelo, and S. Ponziani, "Vote for me! Election control via social influence in arbitrary scoring rule voting systems," in Proceedings of the 18th International Conference on Autonomous Agents and MultiAgent Systems, 2019, pp. 1895-1897.

[7] H. Rosyid, "Pelaksanaan pendidikan politik oleh DPD Partai Gerindra Jawa Timur dalam rangka menghadapi Pemilu Serentak 2019 (Studi pada DPC Partai Gerindra Kabupaten dan Kota Mojokerto)," Humanis J. Ilmu-Ilmu Sos. dan Hum., vol. 11, no. 1, pp. 29-38, 2019.

[8] Z. Arman, "Analisis Terhadap Pengujian UndangUndang Nomor 42 Tahun 2008 Tentang Pemilihan Umum Presiden Dan Wakil Presiden," J. Cahaya Keadilan, vol. 7, no. 1, 2019.

[9] T. Penyusun and N. K. P. U.-U. Dasar, "Negara Republik Indonesia Tahun 1945: Latar Belakang," Proses, dan Has. Pembahasan, vol. 2002, 1999.

[10] J. W. Van Deth, "Studying political participation: Towards a theory of everything," in joint sessions of workshops of the European consortium for political research, Grenoble, 2001, pp. 6-11.

[11] J. Elster, R. Slagstad, and G. Hernes, Constitutionalism and democracy. Cambridge University Press, 1988. 
[12] S. N. Wijayanti and T. Purwaningsih, "Laporan Akhir Tahun Pertama Penelitian Hibah Bersaing: Desain Pemilihan Umum Nasional Serentak dalam Perspektif Hukum dan Politik. Yogyakarta," Repos. umy. ac. id/bitstream/handle/123456789/2227/Laporan Akhir Desain Pemilihan Umum Nas. Serentak dalam Perspekt. Huk. dan Polit. pdf, 2015.

[13] C. Lay, H. Hanif, and N. Rohman, "The Rise of Uncontested Elections in Indonesia: Case Studies of Pati and Jayapura," Contemp. Southeast Asia, pp. 427448, 2017.

[14] S. Azis, "Presidential threshold policy in Indonesian presidential election of 2019," Stud. Humanit., no. 4, 2018.

[15] U. Fionna and F. E. Hutchinson, "Indonesia's 2019 Elections: A Fractured Democracy?," Asian Aff. (Lond)., vol. 50, no. 4, pp. 502-519, 2019.

[16] S. Birch, F. Millard, M. Popescu, and K. Williams, Embodying democracy: Electoral system design in postCommunist Europe. Springer, 2002.

[17] J. Asshiddiqie, "Pengenalan tentang DKPP untuk Penegak Hukum," Makalah disampaikan dalam Forum Rapat Pimpinan Kepolisian Republik Indonesia, Jakarta, 2013.

[18] R. Ristawati, "Pemilihan Umum Presiden dan Wakil Presiden Indonesia dalam Kerangka Sistem Pemerintahan Presidensiil," J. Konstitusi Puskoling Univ. Airlangga, vol. II, no. 1, 2009.

[19] F. Jibreel and F. Jibreel, "Extended Threshold Stable Election Protocol for Wireless Sensor Networks," North Am. Acad. Res., vol. 2, no. 3, 2019.

[20] P. Sirivunnabood, "Thailand's puzzling 2019 election: How the NCPO junta has embedded itself in Thai politics," ISEAS Perspect., no. 44, pp. 3-5, 2019.

[21] L. Ansori, “Telaah Terhadap Presidential Threshold Dalam Pemilu Serentak 2019," J. Yuridis, vol. 4, no. 1, pp. 15-27, 2017.

[22] G. Taylor, "The constitutionality of election thresholds in Germany," Int. J. Const. Law, vol. 15, no. 3, pp. 734752, 2017.

[23] R. Cenedy, "Penyelesaian Sengketa Pemberhentian Penyelenggara Pemilu oleh Dewan Kehormatan Penyelenggara Pemilu (DKPP)(Studi Kasus Putusan DKPP No. 91/DKPP-PKE-III/2014)," UNES J. Swara Justisia, vol. 1, no. 3, pp. 338-352, 2019.

[24] R. Rani, D. Kakkar, P. Kakkar, and A. Raman, "Distance based enhanced threshold sensitive stable election routing protocol for heterogeneous wireless sensor network," in Computational Intelligence in Sensor Networks, Springer, 2019, pp. 101-122.

[25] R. Solihah, "Peluang dan tantangan pemilu serentak 2019 dalam perspektif politik," JIIP J. Ilm. Ilmu Pemerintah., vol. 3, no. 1, pp. 73-88, 2018.

[26] E. Efriza, “Evaluasi Pemilu Serentak 2019 dan Sistem Presidensial," J. Renaiss., vol. 4, no. 1, pp. 495-503, 2019.

[27] M. Lane, "The 2019 Indonesian Elections: An Overview," 2019.

[28] A. Alhamid and A. Perdana, "Presidentialized Party di Indonesia: Kasus Perilaku PDI-P dalam Pencalonan Joko Widodo pada Pilpres 2014," J. Polit., vol. 3, no. 2, pp. 237-264, 2018. 